\title{
A Relative Assessment of Organic Waste Management through Vermicomposting
}

\author{
Dr. Bhawana Asnani \\ Assistant Professor, Polytechnic in Home Science, Junagadh Agricultural University, Amreli-365601, Gujarat
}

\begin{abstract}
Waste Management comprises the sum of all measures for the avoidance and minimization also because the controlled and environmentally acceptable disposal of waste of all types' i.e. domestic waste also as commercial and industrial waste. Landfill, Incineration and Composting are the three methods normally used for management of organic and inorganic wastes. Present study was undertaken to find out the effect of vermi-composting on the nutrients availability from different types of organic waste available from kitchen of Hostel, farm of Krishi Vigyan Kendra and water body of Amreli. Vermicompost helps in further enhancement of nutrients and improve the quality of compost irrespective of type of waste due to the action of earthworms. The compost prepared from kitchen waste has highest nutrient composition (viz. NPK, C:N and C:P ratio) followed by farm waste and water hyacinth. The vermicomposting is a cost effective and simple technology which can be easily learned and adopted to treat organic waste effectively.
\end{abstract}

Keywords — Organic Waste; Vermi-composting; Vermi-culture

\section{Introduction}

The word environment is very broad in itself. It consists of a number of natural resources in terms of air, water, trees, etc. The population on earth is increasing dayby-day and simultaneously the demand of foods, clothing and shelter is increasing. New industries are being set up to fulfill needs of the people. Thus, these growth indicators of population industrialization and urbanization have started polluting the environment. An increasing population and diminishing land area have also created problems of dayto-day garbage disposal. The problem of environment management is becoming a matter of great concern not only in India, but all over the world. Increasing population, industrialization and urbanization have resulted in acute environmental problems. Improper handling or neglect of waste affects the environment and health of living beings, whereas its appropriate management ensures conservation of environment and better health of living beings. Our ecological balance is being, disturbed mainly because of two types of wastes namely:-

- Industrial waste which is mostly inorganic and is usually being disposed in big rivers or sea.

- Organic waste available from kitchen, fruits and vegetables, market, farm and aquatic plants waste from lakes and water bodies etc.

Waste Management comprises the sum of all measures for the avoidance and minimization also because the controlled and environmentally acceptable disposal of waste of all types' i.e. domestic waste also as commercial and industrial waste. The area of waste disposal comprises of the following disposal stages:

- Waste collection and transport

- Waste treatment
- Intermediate waste storage

- Waste recycling and

- Waste dumping (land fill)

\section{Waste Management Methods}

The following methods are normally used for management of organic and inorganic wastes:

- Landfill

- Incineration

- Composting

Landfill : The waste from cities is collected, buried and covered at specified sites outside the cities. Once the waste reaches the landfill sites, it is compacted, thereby excluding oxygen and so speeding up the generation of gas. The covered material is used to seal the site to further promote anaerobic digestion. Landfill Gas can be Used in Three Ways:-

- Directly in kilns, boilers and furnaces if there is a suitable customer nearby.

- For the generation of electricity, either for use locally or for sale to the electricity generation companies.

- For upgrading to higher quality fuel such as liquid natural gas. (The calorific value of landfill gas is approximately half that of natural gas). The limitation of landfill method is the requirement of vast areas of land and transportation cost of waste material.

Incineration : This method of waste management is commonly used for management of municipal solid waste of cities in developed countries. Incineration is very useful in reducing the volume of refuse which is reduced by 90 per cent by this process. However, newly developing 
environmental awareness may hamper the further growth of incineration. The gases created during the incineration contain highly toxic substances which if released directly, are very harm full for the environment. It requires the implementation of strict emission standards so that these hazardous gases are not released directly into the environment.

Composting: The word 'compost' conjures up pictures of an untidy heap of assorted kitchen and vegetable remains at the far end of the garden. A scientific definition of composting would describe it as the biological decomposition of organic wastes under controlled conditions, the most important being that they are aerobic and at elevated temperatures. The process yield an end product which is relatively stable and can safely be applied to the soil. This biological decomposition is carried out by micro-organisms which break down the complex organic substances into carbon dioxide, water and a residue, compost. Further, biological processes in the soil turn compost into humus.

- Mature compost may be a valuable substance, it can act as:

- A soil conditioner improving soil structure, especially for heavy clay soil. Compost also retains moisture then helps to enhance light sandy soils. It reduces erosion, and helps in preserving the nutrients, preventing them from being washed out of the soil.

- A soil fertilizer encouraging an active rootage.

- Mulch if applied around plants will smoother small weeds and prevent the surface soil from drying out.

- A peat substitute for use in potting mixtures.

Household refuse contains high proportion of organic materials which are suitable for composting. The compostable fraction of domestic waste includes food scraps, animal wastes and soft plant materials. However, not all materials of biological origin decompose fully during composting (TERI, 1998).

Amongst all these waste management methods, composting is the only safe and clean method which can be applied at house hold level, farm level and on community basis for recycling of organic waste into plant nutrient supply system. Vermicomposting is improved method of composting which harnesses the potential of earth worms as natural bio-reactors is conjunction with micro-organisms to process waste organic matter into good quality compost.

\section{Type of Wastes}

Different types of plant organic waste which can be utilized for recycling as plant nutrients through vermicomposting can be grouped as under:
Waste from Kitchen (City Refuse): There is availability of plenty of city refuse which is not recycled properly and can become an environmental hazard. According to Salvi, an individual creates about $0.4 \mathrm{~kg}$ waste per day. Accordingly, an amount of about 44.8 million tones of city refuse will be produced by 307 million urban populations in the year 2001. Forty per cent of this refuse (17.9 MT) will be compostable and can be recycled as value-added product for plant nutrient system. Table 1 shows the availability of city refuse of five consecutive decades from the year 1997 to 2011. In 2001, we can observe that city refuse of about 44.8 MT was disposed off. Further, after a decade, i.e., in 2011 with the 377.11 million population city refuse was 59.3 MT (both non-compostable and compostable).

Farm Waste: Several industrial including agro-based industries and dairy farms have started their own vermicompost units in their respective premises to convert the organic solid and liquid wastes into vermicompost and worm biomass. Vermicomposting is the best method of recycling agricultural and animal wastes into agriculture. Vermicomposting of animal wastes and agricultural residues result in higher nutrients content within six weeks. The major sources of organics which need to be harnessed into the plant nutrient supply system are crop residues, biomass of weeds such as water hyacinth, organic wastes from fruits and vegetables production and household wastes. It has been reported (Singh) that about one-third of the crop residues produced is available for recycling as manure. In 1996, the availability of crop residue was about 357 million tones of which about 180 million tones could have been utilized for recycling. Similarly, our country produces more than 30 million tones of fruits and 60 million tones of vegetables every year. Thus, organic waste can be gainfully utilized by recycling.

Aquatic Plant Waste: Water hyacinth growth abundantly in fresh water ponds, pools, lakes and reservoirs. It is known as one of the most dangerous plants. The growth of water hyacinth is very harmful for the fresh water. The plants cover creates obnoxious smell, coloring matter and suspended particulate in the water. It has been expounded by Arthanari that oxygen depleting load of one hectare of water hyacinth mat is equivalent to the sewages created by 80 persons per day. This action lowers the natural ability of water body to absorb organic pollution and creates septic and odorous conditions. The best solution to the problem created by water hyacinth is to utilize it as soil additive by recycling through vermicomposting. It has been reported that it produces valuable compost consisting of 0.75 per cent $\mathrm{N}, 0.74$ per cent $\mathrm{P}$ and 0.34 per cent $\mathrm{K}$, respectively, if used in combination of other materials like biogas slurry and press mud. Deshpande expressed that in comparison to ordinary 
compost, the vermicompost has following distinct advantages:

- It has three times nitrogen.

- It has seven times more phosphate.

- It has eleven times more potash.

- It has four times more nitrogen fixing bacteria.

- Ordinary soil has $10 \mathrm{ml} / \mathrm{ha}$ water holding capacity. However, in presence of earth worms it may increase upto $100 \mathrm{ml} / \mathrm{ha}$.

- It increase the content of some useful micronutrients such as lignin and linguine, thereby disease resistance capacity of plant improves.

- One earthworm eats one and half times more soil as compared to its weight and converts it to 100 per cent fertilizer.

- One earthworm eats one and half times more soil as compared to its weight and converts it to 100 per cent fertilizer.

- Vermiculture saves 80 per cent water content of the soil after fulfilling requirement of plants to the extent of 20 per cent moisture. Thereby increases the water table in the soil.

Involvement and participation of homemaker at every stage from planning to conversion is a prerequisite to ensure the optimum reuse of the products coming out of the waste. As the homemakers are associated with the waste, as the generator of waste, they should be trained and exposed to handling and utilization of the waste as consumers. So, this study was designed which aimed to assess the existing pattern of garbage disposal and awareness about vermiculture technique. The objectives of the study were:-

- To compare the suitability of conservation composting and vermicomposting from kitchen waste, farm waste and water hyacinth in terms of time and economy.

- To compare the availability of nutrients from conventional and vermicompost.

\section{Methodology}

Kitchen waste was collected from Polytechnic in Home Science Girls' Hostel, farm waste was in the form of Sesame (Sesamum indicum), Tuar (Cajanas cajan), Wheat (Triticum Aestivum), and Sunflower (Helianthus annus) straw collected from Agriculture Research Station and Krishi Vigyan Kendra Farm, and water hyacinth was collected from Small Lake situated near Kamnath Temple, Amreli, Gujarat. Pits of $1.0 \mathrm{~m}$ x $0.6 \mathrm{~m}$ x $0.45 \mathrm{~m}$ were dug at a higher elevation under the shade of tree. All the three types of waste was chopped into small pieces and mixed with cowdung in the ratio of 1:4 (w/w) and kept for 15 days before filling into pits. These pits were then filled with a $5 \mathrm{~cm}$ thick base layer of coconut coir. After this it was over layered with $5 \mathrm{~cm}$ layer of bricks and stones followed by $5 \mathrm{~cm}$ thick cowdung. Vermicompost containing two hundred adults of earthworms was uniformly distributed above the layer of fresh cowdung. It was then covered with 15 days old incubated mixture of organic residue and cowdung mixture. Each layer was watered to have an optimum moisture content of 30 per cent. Compost pits were examined at regular intervals. At the end, material was harvested, air dried, weighed and stored. Samples of original wastes and composts collected and analyzed in the laboratory to find out their nutrient composition for different types of wastes.

\section{Results \& Discussion}

The result of present study has shown that vermiculture technique of vermicomposting on the availability of nutrients from different types of organic waste available from hostel kitchen, KVK farm and nearby water body of Amreli. The major emphasis of the study was to recycle the plant organic waste into a value-added product, which could be directly used as a plant nutrient.

\subsection{Composition of Wastes Before Composting}

- Availability of major nutrients (NPK) and micronutrients ( $\mathrm{Mn}, \mathrm{Zn}, \mathrm{Cu}, \mathrm{Fe}$ ) for the original wastes without composting was maximum in kitchen waste followed by water hyacinth and farm waste.

- Nitrogen availability for kitchen waste was 0.43 per cent, farm waste 0.21 per cent and water hyacinth 0.32 per cent.

- Similarly, availability of phosphorous was 0.115 per cent, 0.110 per cent and 0.112 per cent for kitchen waste, farm waste and water hyacinth respectively.

- Potassium availability was 0.61 per cent, 0.45 per cent and 0.38 per cent for three types of waste respectively.

- Among the micro-nutrients, Mn and Zn were highest in water hyacinth followed by kitchen waste and farm waste. On the other hand, kitchen waste was rich in $\mathrm{Cu}$ and Fe compared to water hyacinth.

- Data further showed that C:N ratio was widest in case of water hyacinth (90.4) followed by farm waste (80.2) and kitchen waste (52.5). Similar to $\mathrm{C}: \mathrm{N}$ ratio, C:P ratio was widest in water hyacinth and was followed by kitchen waste and farm waste.

\subsection{Composition of Wastes After Composting}

Major Nutrients: Nutrient composition was also observed after composting of all three types of waste. It was noticed that the nutrients composition was more after vermicomposting as compared to simple compost (Table 2).

- Increase in nitrogen content was from 0.44 per cent to 1.56 per cent for three types of waste after composting and vermicomposting. Maximum nitrogen content of 1.56 per cent was obtained in vermicomposting 
prepared from kitchen follow by 1.32 per cent in case of water hyacinth and 0.84 per cent in case of farm waste.

- Phosphorous content of all the three types of waste was more in case of vermicompost to that of simple compost. Percentage of phosphorus content for vermicompost varied between $0.425-0.489$ percent, whereas it was only from $0.327-0.357$ percent for simple compost.

- Potassium content of the compost was higher for all the three types of waste after a 45 days period of incubation. For simple compost potassium content was 0.71 percent for kitchen waste, 0.45 per cent for farm waste and 0.62 per cent for water hyacinth, whereas in case of simple compost and it was $1.72,1.60$ and 1.62 percent in case of vermicompost for all the three types of waste, respectively, at the end of 45 days period.

Micro-nutrients: Micro-nutrients ( $\mathrm{Mn}, \mathrm{Zn}, \mathrm{Cu}$ and $\mathrm{Fe}$ ) of all the three wastes increased in vermicompost as compared to simple compost.

- Per cent increase for Mn was 90.26 and 96.05 for kitchen waste, 222.72 to 306.81 for farm waste and 107.86 to 184.26 for water hyacinth.

- Percent increase for $\mathrm{Zn}$ was 161.11 to 233.33 for kitchen waste, 95.07 to 85.91 farm waste and 65.13 to 127.52 for water hyacinth.

- For $\mathrm{Cu}$ the corresponding increases were 58.33 to 102.77 percent for kitchen waste, 115.38 to 123.07 percent for farm waste and 86.66 to 170.0 percent water hyacinth.

- For Fe the increases were 79.38 to 90.72 percent for kitchen waste, 60.95 to 71.61 percent for farm waste and 76.47 to 105.88 percent for water hyacinth.

$C: N$ and $C: P$ Ratio: It is indicated in the figure 2 clearly that there was an increase in nitrogen and phosphorous content by composting process.

- C: $\mathrm{N}$ ratio which was $52.5,80.2$ and 90.4 in the original kitchen waste, farm waste and water hyacinth respectively decreased to $27.5,28.9$ and 32.5 after simple composting and 24.3, 26.5 and 27.5 after vermicomposting after a period of 45 days (Figure 1 ).

- Similarly, C: P ratio of composts also narrowed down from 153.0-258.21 to 52.37-77.5 for vermicompost and
37.51-82.45 for simple compost. It is indicated that vermicomposting helped in increasing the availability of phosphorous content of the compost from different types of waste materials (Figure 2).

Yield and Quality of Compost: Yield of compost was more in simple composting compared to vermicomposting for three types of wastes. Yield of compost in simple composting was $10.174,8.693$ and $6.447 \mathrm{~kg} /$ pit for kitchen waste, farm waste and water hyacinth compared to 5.721, 6.920 and $4.096 \mathrm{~kg}$ for three types of wastes after vermicomposting, respectively. It was due to nutrient enrichment due to vermicomposting process. The reason for higher yield of compost in case of simple composting was lesser breakdown of plant constituents and therefore lesser loss of $\mathrm{CO}_{2}$ as compared to vermicomposting. Quality of compost was better in case of vermicompost compared to simple compost irrespective of wastes indicating that the compost prepared with the help of earthworm had more friability due to the grinding action in their gut coupled with microbial action.

Earthworm Multiplication: Earthworm multiplication was more in kitchen waste followed by farm waste and water hyacinth at both the stages of composting. Corresponding per cent increase was 193.5, 128.5 and 138.0 per cent at 45 days intervals for kitchen waste, farm waste and water hyacinth, respectively (Figure 3).

\section{Conclusion}

The result of the study proved emphatically that the vermicomposting is a very clean and scientific method for management of organic waste. It provides nutrient rich high quality manure which would be very useful in increasing the farm production. Vermicompost helps in further enhancement of nutrients and improve the quality of compost irrespective of type of waste due to the action of earthworms. The compost prepared from kitchen waste has highest nutrient composition followed by farm waste and water hyacinth. The vermicomposting is a cost effective and simple technology which can be easily learned and adopted to treat organic waste effectively.

Table 1: Potential Availability of City Refuse (1997 to 2011 MT/yr)

\begin{tabular}{|l|l|l|l|l|l|}
\hline Particulars & $\mathbf{1 9 7 1}$ & $\mathbf{1 9 8 1}$ & $\mathbf{1 9 9 1}$ & $\mathbf{2 0 0 1}$ & $\mathbf{2 0 1 1}$ \\
\hline $\begin{array}{l}\text { Urban } \\
\text { (million) }\end{array}$ & 109.1 & 159.5 & 217.6 & 307.0 & 377.11 \\
\hline $\begin{array}{l}\text { City Refuse } \\
\text { Non-Compostable (60\%) } \\
\text { Compostable (40\%) }\end{array}$ & 9.6 & $\begin{array}{l}14.0 \\
9.4\end{array}$ & $\begin{array}{l}19.1 \\
12.7\end{array}$ & $\begin{array}{l}26.8 \\
17.9\end{array}$ & $\begin{array}{l}34.9 \\
24.4\end{array}$ \\
\hline City Refuse Total & 16.0 & 23.3 & 31.8 & 44.8 & 59.3 \\
\hline
\end{tabular}

Note: - City refuse = urban population $\times 0.4 \mathrm{~kg} / \mathrm{rrban}$ dweller $/$ day $\times 365$ days.

Source: TERI6 and Census of India2. 
Table 2: Availability of Nutrient (Per cent) in Different Types of Waste of after Composting and Vermicomposting at Different Time Intervals

\begin{tabular}{|c|c|c|c|c|c|c|c|c|c|c|c|c|}
\hline \multirow{4}{*}{$\begin{array}{l}\text { Waste } \\
\text { Material }\end{array}$} & \multicolumn{12}{|c|}{ Nutrients (Percent ) } \\
\hline & \multicolumn{6}{|c|}{ Simple Compost } & \multicolumn{6}{|c|}{ Vermicompost } \\
\hline & \multicolumn{3}{|c|}{30 days } & \multicolumn{3}{|c|}{45 days } & \multicolumn{3}{|c|}{30 days } & \multicolumn{3}{|c|}{45 days } \\
\hline & $\mathrm{N}$ & $\mathrm{P}$ & $\mathrm{K}$ & $\mathrm{N}$ & $\mathrm{P}$ & $\mathrm{K}$ & $\mathrm{N}$ & $\mathrm{P}$ & $\mathrm{K}$ & $\mathrm{N}$ & $\mathrm{P}$ & $\mathrm{K}$ \\
\hline Kitchen Waste & 0.63 & 0.265 & 0.64 & 0.76 & 0.362 & 0.71 & 0.93 & 0.395 & 0.83 & 1.56 & 0.489 & 1.72 \\
\hline Farm Waste & 0.4 & 0.240 & 0.47 & 0.47 & 0.362 & 0.54 & 0.57 & 0.355 & 0.78 & 0.84 & .0425 & 1.60 \\
\hline $\begin{array}{l}\text { Water } \\
\text { Hyacinth }\end{array}$ & 0.72 & 0.245 & 0.52 & 0.83 & 0.327 & 0.62 & 0.84 & 0.387 & 0.82 & 1.32 & 0.487 & 1.62 \\
\hline
\end{tabular}

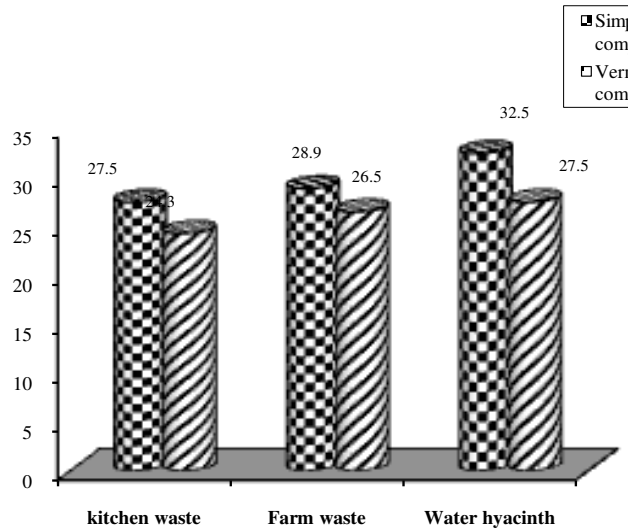

Fig. 1: Availability of $\mathrm{C}: \mathrm{N}$ in different types of waste after composting and vermicomposting after 45 days

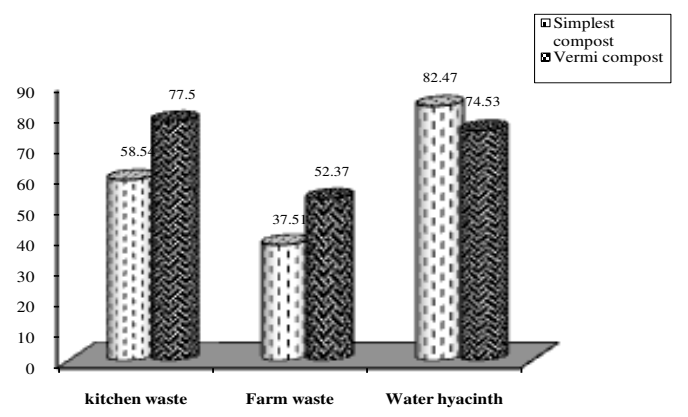

Fig.2: Availability of C:P in different types of waste after composting and vermicomposting after 45 days

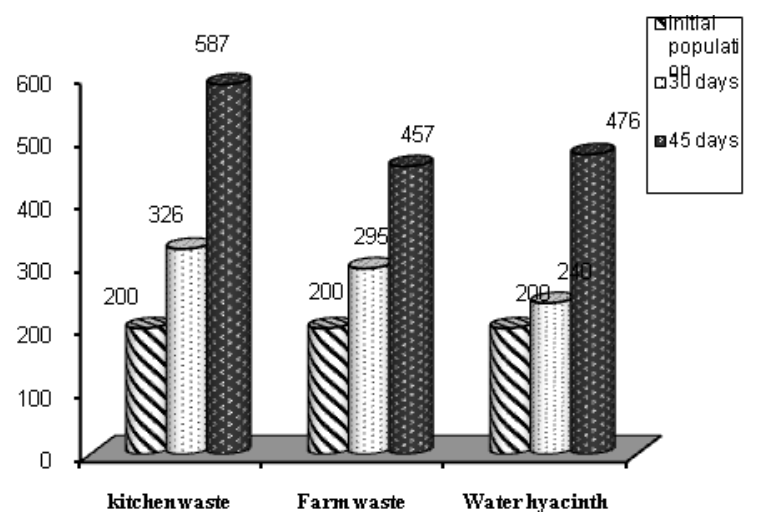

Fig.3: Earthworms population at different stages of vermicomposting (per kg of dry vermicompost) in different types of waste

\section{References}

[1] Arthanari P.M., (1997) Vermicomposting of Water Hyacinth, Kisan World, Desh Publication, Madras- 14 (24): 6, 42 .

[2] Census of India (2011).

[3] Deshpande W., (1996). Organic Farming. Environmentally sound technologies for women in agriculture. International Federation for Women in Agriculture, 71-74.

[4] Salvi P. (1997). Composition of Solid Waste. Integrated Solid Waste Management, Hamburger Umwelt Institute and Save Bombay Committee, Mumbai. 14-18 .

[5] Singh G.B., (1996) Strategy for Balanced Usage, Hindu Survey of Indian Agriculture ICAR, New Delhi, 151-152.

[6] TERI, (1998) Energy Demand: Domestic Sector, TEDDY, Tata Energy Research Institute, New Delhi, 241-250. 